\title{
INTELLECTUAL CAPITAL IN PUBLIC SECTOR
}

\author{
Novi Swandari Budiarso ${ }^{1}$ \\ ${ }^{1}$ Accounting Program, Economics and Business Faculty, Sam Ratulangi University, Jl. Kampus Bahu, Manado \\ City, 95115, Indonesia \\ Corresponding e-mail : novi.sbudiarso@unsrat.ac.id
}

\begin{abstract}
This study explores the way in which intellectual capital characteristics contribute towards a competitive advantage to public sector firms, particularly-State Owned Enterprises (SOEs) in Indonesia. The purpose of this study was to investigate the relationship between the intellectual capital and performance of public sector firms. Another purpose was to find out the difference of SOEs and non SOEs listed on Indonesian Stock Exchange regarding the effect of intellectual capital on financial performance The motivation based on the opinion that public sector in Indonesia had a bad performance compares to private sector. In government context human capital include competence, level of knowledge and integrity. Structural capital consist of culture and system or bureaucracy. Customer capital pertaining services to public. The sample consist of 36 firms were listed in Indonesia Stock Exchange, 18 SOEs and 18 non SOEs. Data were drawn for three years, 2010-2012. It was an empirical study using multiple regression model and independent sample t test for the data analysis. The paper tests elements of VAIC ${ }^{T M}$ and financial company's performance. The findings show that: as partial, the components of intellectual capital (VAIC $\left.{ }^{T M}\right)$, physical capital have a significantly influences to firms performance, but human capital and structural capital have no significantly influences to firms performance.
\end{abstract}

Keywords : intellectual capital, physical capital, human capital, structural capital, financial performance

JEL Classification : H11, H53, H61

Article info:

Received 3 May 2019

Revised 2 June 2019

Accepted 10 June 2019

Available online 15 June 2019

\section{INTRODUCTION}

The shift to knowledge economy marked by the growing importance of intangible assets. Knowledge assets are becoming important role in the value creation, because can improve the performance and lead to the firm competitive advantage. Intellectual capital can be thought of as the knowledge-based equity of a company, International Federation of Accountants (1998). But the tradisional financial reporting can not sound the IC terms. Substantial differences often exist between the market and book values of companies. Much of these differences can be explained by intellectual capital assets not recognised in company balance sheets. This has presented companies with a new challenge - how to account for intellectual capital, Brennan and Connell (2000). In 1993 Leif Edvinsson, in a supplement to Skandia's Annual Report, used for the first time the word Intellectual Capital instead of the accounting term Intangible Assets Edvinsson (1997). Skandia AFS, a Swedish financial services company, was one of the on to develop one of the most important models, the Skandia Navigator, for managing intellectual capital. Sveiby who has carried out a considerable amount of the pioneering 
research on intellectual capital management points out that the increasing importance of intellectual capital may require a fundamental shift in the way we think about organisations. How about Intellectual Capital in public sector? In Government contex human capital include competence, level of knowledge and integrity. Structural capital consist of culture and system or birocracy. Customer capital pertaining services to public. Human capital, Local governance and Education Performance a Survey the Quality of Local Education Performance a Survey of the Quality of Local Education Governance in 50 Indonesian Districts suggested that only $12 \%$ local government consolidate education development planning. This encumbrance for effort to reform management based education. Structural capital, bureaucracy became burden for society, because the tortuous process and system and the bureaucrats that corrupt. Relationship capital, who are the state customer? society did not threat like a customer, this make quality of public service poorly disappointing.

The case for privatization, whether defined in a broad or narrow sense, has been forcefully made by its advocates against the backdrop of the much advertised poor performances of state- owned enterprises (SOEs) and theoretical arguments relating to the efficiency of private firms over public enterprises. In many countries state enterprises are in very poor state. Political interference, corruption, lack of vision, a dearth of skills, inadequate investment, all these factors have lead to huge losses. They are being kept on support, which comes in the form of state subsidies and protection. State enterprises are fuelled by money. Governments spend millions subsidising poor management. Consumers pay millions for the high price of inefficiency. Workers lose millions as a result of low wages and poor prospects. However, many state enterprises can seem large, imposing and secure from the outside. But a closer look and what do we see? Stalled production lines, crumbling buildings, rusting vehicles, idle workers, unsettled overdrafts and unpaid bills.

These institutions in fact, should be productive national assets, making a contribution to the progress and welfare of the country. But years of politicisation, corruption, mismanagement, inadequate investment, lack of vision and discipline have stripped them of their potential making them colossal liabilities. Over the years enormous amounts of money have been spent to sustain ailing state enterprises. Governments borrow heavily from the state banks and from foreign financial institutions. Aid donors will no longer support wasteful expenditure. Therefore, either unproductive state enterprises will have to be shut down or the entire economy will go bankrupt. It is these unsettling realities that makes a strong case for privatisation in most developed and less developed countries. State enterprises have to be energised such that they contribute to the economy. Privatisation therefore, is a critical component of reform in most countries. The generally accepted position on privatisation, currently derives from long experience with failed attempts at reforming public enterprises. For years governments have been taking effort to improve state enterprise performance with limited success. The costs have been high. In many countries inefficient state enterprises drain budgets, divert resources from health and education, damage the banking sector, and limit the development of the private sector.

Indonesian government have to start concerning about intellectual capital in public sector. This is the important resources for survive in the economic based knowledge. Put the knowledge as a vision on economic development. Using resource based value this study suggested intellectual. Capital as a competitive advantage, leads to state capabilities performance. There have been numerous articles investigating the relationship between Intellectual Capital and performance of Indonesian firms. But only several of them attempt to analyze the effect of IC to performance of specific type of public sector, particulary SOEs. Intellectual Capital in Indonesia is widely recognize. 


\section{LITERATURE REVIEWS}

Haanes and Lowendahl (1997) classified Intellectual Capital: source of competency and relationship; Lowendahl (1997) divided source of competensi and relationship in to sub categorical: individual and kolektif; Stewart (1997) classified: human capital, structural capital and customer capital: The Danish Confederation of Trade Unions (1999) divided: human, system and market. The European Commission (MERITUM,2001 in Hong, 2007) classiefied: human capital, structural capital and relationship capital.

Bontis et al (2000) investigate the inter-relationships among the human capital, structural capital and customer capital and business performance. Results showed that structural capital has a positive relationship with business performance regardless of industry. Muhammad and Ismail (2009) investigated the relationship between intellectual capital efficiency and firm's performance on Malaysian financial sectors. The study found that intellectual capital has significant and positive relationships with company's performance measured by profitability and Return on Assets (ROA). Zehri et al (2012) explores the impact of intellectual capital and business performance from the standpoint of financial performance, the marketplace and economics. The results found a positive and significant association between the components of intellectual capital and economic performance. And a positive association between financial performance and components of intellectual capital. The paper analyses the structure of the intellectual capital and its influence on the economic performances based on the VAIC model. The results suggest that, in crisis time, the development of companies is influenced by the human and the structural capital, while profitability is additionally linked to the financial capital through the value added intellectual capital coefficient. Another study of relationship between intellectual capital and firms performance proposed by (Chu et al, 2011; Chen at al, 2005; Cabrita and Bontis,2008; Bannany, 2008, Beshkooh et al, 2013).

Gan and Saleh (2008) examines the association between Intellectual Capital and corporate performance of technology-intensive companies (MESDAQ) listed on Bursa Malaysia by investigating whether value creation efficiency, as measured by Value Added Intellectual Capital $\left(\mathrm{VAIC}^{\mathrm{TM}}\right.$ ), can be explained by market valuation, profitability, and productivity. The results also indicate that physical capital efficiency is the most significant variable related to profitability while human capital efficiency is of great importance in enhancing the productivity of the company. The impact of Intellectual capital on public sector, particulary in institution, examined by Baye and Jean (2014) and discovered that financial institutions still depend very much on capital employed since it is positively significant to profitability, while human capital and structural capital are not. Datta (2013) focuses on how the enterprises utilize intellectual capital, in order to strengthen the competitiveness of enterprises. And concluded successfully the relationship between IC and a firm's EPS. Ramirez (2013) shows that the components of intellectual capital (human, structural and relation) is the most relevant for publication which means that the information most valued by the different stakeholder groups is that related to relational capital, followed by human and then lastly structural capital.

Public Sector Enterprises have to faced the competitive strugel with the private sector. Barney (2001) argues that sustained competitive advantage derives from the resources and capabilities a firm controls that are valuable, rare, imperfectly imitable, and not substitutable. These resources and capabilities can be viewed as bundles of tangible and intangible assets. Resource-based theory treats enterprises as potential creators of value-added capabilities,and the underlying organizational competences involves. A firm's resources consist of all assets both tangible and intangible, human and nonhuman that are possessed or controlled by the firm and that permit it to devise and apply value-enhancing strategies (Barney, 1991; Wernerfelt, 1984). 
Brown and Duguid (1998) address that the organization of knowledge itself. They suggested that capabilities could be a source of competitive advantage for an organization.The key premise is that knowledge will reside indifferent areas of the organization. Although VAIC is an aggregate measure for corporate intellectual ability, if investors place different values for the three components of VAIC, the model using the three components of VAIC will have greater explanatory power than the model using the aggregate one, (Chen et al, 2005). The following hypotheses are presented based on theoretical basics and research background:

H1 : there is a significant relationship between VACA and financial performance.

$\mathrm{H} 2$ : there is a significant relationship between VAHU and financial performance.

H3 : there is a significant relationship between STVA and financial performance.

$\mathrm{H} 4$ : there is a difference in financial performance between state owned enterprises and private owned enterprises in regard to the impact of intellectual capital

\section{RESEARCH METHOD}

This study used 18 SOEs listed in Indonesian Stock Exchange, during 2010 to 2012 as a sample. First, multiple regression implies to find the relationship between intellectual capital and firm performance.Second, to examine the different between intellectual capital in state enterprises and private enterprise,this study used independend $t$ test. This study conducts multiple linear regression for hypothesis testing on models as follows :

$$
\mathrm{ROA}=\alpha+\beta \mathrm{VACA}+\beta \mathrm{VAHU}+\beta \mathrm{STVA}+\epsilon
$$

The intellectual capital measured by Value Added Intellectual Coefficient (VAIC ${ }^{\mathrm{TM}}$ ) and profitability measured by Return On Assets. The VAIC ${ }^{\mathrm{TM}}$, model proposed by Pulic (1998) which intends to measure the extent to which a company produces added value based on intellectual capital efficiency or intellectual resources. The intellectual ability of a company shows how efficiently they have been used. The VAIC ${ }^{\mathrm{TM}}$ method is designed to provide information about the value creation efficiency of tangible and intangible assets within a company. The model starts with a company's ability to create value added (VA). VA is the difference between sales (OUT) and inputs (IN) and is represented by the following equation:

$$
\mathrm{VA}=\mathrm{OUT}-\mathrm{IN}
$$

where, OUT is outputs (the revenue and comprise all the products and services sold on the market) and IN is inputs (all the expenses incurred in earning the revenue except manpower costs, labour expenses are not included). Furthermore, while employing physical capital (CA) then the model of this study is :

$$
\mathrm{VACA}=\mathrm{VA} / \mathrm{CA}
$$

This is an indicator for the VA created by one unit of physical capital. The relation of VA and HC. The human capital coefficient (VAHU) shows how much VA is created by a dollar spent on employees.

$$
\mathrm{VAHU}=\mathrm{VA} / \mathrm{HC}
$$

The next model is structural capital coefficient (STVA) which shows the contribution of structural capital (SC) in value creation. STVA measures the amount of SC needed to generate a dollar of VA and is an indication of how successful SC is in value creation.

$$
\text { STVA }=\text { SC/VA }
$$

The final is the sum of all coefficients.

$$
\mathrm{VAIC}^{\mathrm{TM}}=\mathrm{VACA}+\mathrm{VAHU}+\mathrm{STVA}
$$

The profitability measured by return on assets, reflection of earnings and firm efficiency in using total asset which calculted by net income over average total assets. To examine the different on intellectual capital in state enterprise and private enterprised, this study used independent $\mathrm{t}$ test. 


\section{RESULTS AND DISCUSSIONS}

\subsection{Results}

Table 1 presents correlation analysis for testing dependent and independent variables as initial exploration of their relationships. VACA and VAHU was significantly positively correlated with ROA as financial indicators $(\rho<0.01)$. Reflecting the importance of physical capital and human capital in profitability of SOEs. This study finds that physical capital has strong correlation with profitability as its coefficient is 0.616 while human capital has moderat correlation as its coefficient is 0.453 which imply that SOEs still count heavely on physical capital compare with human capital and structural capital.

Table 1. Correlation analysis of ROA, VACA, VAHU, and STVA

\begin{tabular}{lllll}
\hline & ROA & VACA & VAHU & STVA \\
\hline ROA & 1.000 & & & \\
VACA & $0.616^{* *}$ & 1.000 & & \\
VAHU & $0.453^{* *}$ & $0.743^{* *}$ & 1.000 & \\
STVA & 0.048 & -0.171 & -0.045 & 1.000 \\
\hline
\end{tabular}

** Correlation is significant at the 0.01 level (2-tailed).

Table 2 presents the results of hypothesis $\mathrm{H} 1$ to $\mathrm{H} 4$. To test the quality of the linear fit of the model, we calculated the coefficient of multiple correlations or the explanatory power of the model " $\mathrm{R}^{2}$ " adjusted. The result indicates a low adjusted R-square (0.404), which means that the independent variables are poor explanatory factors of variations in the dependent variable. However, this statistic increases systematically with the number of explanatory variables in the model. In this sense, we calculate the derivative of $\mathrm{R}^{2}$ called correlation coefficient adjusted. The table 4.2 shows that the model has a satisfactory explanatory power and indicates that $36.90 \%$ of the variation in firm performance is explained by the components of intellectual capital.

Table 2. Regression results of intellectual capital

\begin{tabular}{|c|c|c|}
\hline \multirow[b]{2}{*}{ Independent variables } & \multicolumn{2}{|c|}{ Dependent variable : ROA } \\
\hline & Coefficients & t-stats \\
\hline Constant & 4.486 & 2.166 \\
\hline VACA & 47.231 & $4.040^{*}$ \\
\hline VAHU & -0.109 & -0.244 \\
\hline STVA & 0.818 & 1.442 \\
\hline F-stats (p-value) & & $11.318^{*}$ \\
\hline $\mathrm{R}$ square & 0.404 & \\
\hline Adjusted R square & 0.369 & \\
\hline
\end{tabular}

*significant at 0.05

On analysis on three independent variable, there was physical capital, human capital and structural capital only physical capital is significantly and positively related with the ROA as dependent variables. That means that physical capital efficiency positively influences profitability. This result consistent with previous studies of Muhammad and Ismail (2009), Bontis et al (2000), and Chen at al. (2005) where they found that overall intellectual capital has positive and significant relationships with profitability.

\subsection{Discussions}

The first hypothesis posited a positive correlation between a company's component IC, VACA and its performance. The result of multiple linear regression with regard to financial performance confirm previous studies by Gan and Saleh (2008), Baye and Jean 
(2014), and Zeghal and Maaloui (2010). Result show that physical capital remains a major determinant of financial performance in SOEs, this consistent with the general characteristic of SOEs. To explain this result we argue that the SOEs that listed in Indonesian Stock Exchange, through the reform program contributed to increased profitability in some instances. The important thing, that SOEs managed well their resources, particullary physical as their general characteristic. Because they have to face the competitive with another company's.

The second result hypothesis posited no significant effect of human capital (VAHU) to financial performance. This result confirm previous studies by Riahi-Belkaoui (2003), Chen et al. (2005), and Tan et al. (2007) which have all found a significant positive association between financial performance and components of intellectual capital. This study shows that privatization policy of SOEs, by governments have no effect to the human capital. Contradiction with the general characteristic of SOEs which have number of employees. The explanation of this result show that the human capital, as a resources in SOEs in practices are not consistent with the company strategic goals and the resources are not managed well. Or because the human capital are related to different firm outcomes, including operational performance and employee relation climate. The ownership of company, one of the a important role that have to considered, because they face different in institutional constraints and they search for different human resources models in order to operate effectively in the economy.

The result of the third hypothesis show that the expectations of this study regarding the positive and significant impact on the structural capital of the company and its financial performance is not confirmed. This result confirms the study by Baye and Jean (2014) but contradict with study by Bontis (2000). There is a correlation between structural capital and human capital, the result of this studies shows that human capital no significant effect on financial performance this because structural capital as components of intellectual capital, and consists of the supportive infrastructure, processes, and databases of the organisation without it, the human capital enable to function. SOEs failed to integrating the human capital and structural capital as a potensial resources to get a value creation. Structural capital is the component that can leverage human capital abilty to ensure the efficient pursuit of organizational goals.

Table 3 shows the result for fourth hypothesis where difference between SOEs and non SOEs regarding the effect of intellectual capital to financial performance is tested. The result shows that there is a difference between intellectual capital in SOEs and non SOEs company listed in Indonesian Stock Exchange. It concludes that the privatization of SOEs not maximizing the value of intellectual capital. This may be because previously SOEs company might be faced with difficulties adjusting to professional business practises to build and extend their resources to competitive advantages.

Table 3. Mean difference test of VAIC

\begin{tabular}{clccc}
\hline Variable & $\begin{array}{c}\text { Levene's Test for } \\
\text { Equality of } \\
\text { Variances }\end{array}$ & $\mathbf{F}$ & $\mathbf{t}$ & $\begin{array}{c}\text { Mean } \\
\text { Difference }\end{array}$ \\
\hline VAIC & $\begin{array}{l}\text { Equal variances not } \\
\text { assumed }\end{array}$ & 2.135 & 3.547 & $4.11130^{*}$ \\
\hline
\end{tabular}

*significant at 0.05

\section{CONCLUSION}

Intellectual capital are the main factor for the creation of a company's value added. The differences among company's are how the managed and integrated it to became a competitive advantage. This study has investigated the effect of IC components to financial 
performance, also the differences of SOEs and non SOEs regarding IC effect on financial performance. The results show that physical capital have a significant impact on the financial performance, but the other components, human capital and structural capital have no significant impact to financial performance. The findings suggested that the human capital and structural capital are less of importance for SOEs appeal the physical capital, so physical capital wa valued most.

SOEs still focus in the physical capital to enhance their profitability. During recent period they have to sift the paradigm in managed their resources as the integrated value, this may serve value creation to obtain the competitive advantage. VAIC method could be an important tool for many decision makers in SOEs to integrate IC in their decision process. The results also imply that physical capital efficiency is the most significant variable related to profitability while human capital efficiency and the structural capital is the next one. The results show that private firms and SOEs company have different in managed their IC for profitability. Privatisation often seems the first-best option for enhancing efficiency, but this studies not confirmed that. Corporate governance reform, and greater exposure to competition, not resulting in a significant change in SOEs' role for profitability.

The results of this study has several role in practical implications. The important thing, they allow managers to apply the VAIC method to better manage their IC and to benchmark against the best competitors in their sectors. While the SOEs can also adopt the VAIC method as a potential measure of transparansi disclosure to publik. Even traditional financial statement have a limitation to report on IC. In addition, investors can use the VAIC method to help them select companies for their portfolios that have a track record for continuous creation of VA in an efficient and sustainable way. Finally, governments can use the VAIC method to assess different companies and different sectors in the economy in terms of Value Added of their IC. This may result in better economic policies and an improvement in the management of the new economy. In fact, our findings will support the governance in their decision to compile and disclose the data on VA and approach on the role of IC in value creation.

This study has some limitations. First, this research not incorporate control variables, such as size and debt. Additional research should give more attention to control factors and could eventually introduce other control factors and provide clearer results, if the necessary data were to be available. Second, given that findings from the present study are only use data from 2010 to 2012, future research should be undertaken to examine the data from earlier years. Finally, the present study focuses on SOEs listed in Indonesian Stock Exchange, thus it may not be reflective of all public sector in Indonesian. The future research should obtain data from SOEs that not listed in Indonesian Stock Exchange to more understandbility of public sector IC. Future research should comparing association of IC and other measures financial performance such as retun on equity and growth. Investigate the relationship between intellectual capital and non-financial performance such as customer satisfaction and employee.

\section{REFERENCES}

Bannany, M. (2008). A Study of Determinants of Intellectual Capital Performance in Banks: UK Case, Journal of Intellectual Capital, 9(3), pp. 487-498.

Barney, J. B. (1991) . Firm Resources and Sustained Competitive Advantage. Journal of Management, 17(1), pp. 99-120.

Barney, J., Wright M., and Ketchen, D. J. Jr. (2001). The resource-based view of the firm: Ten years after 1991. Journal of Management, 27. pp. 625-641. 
Baye F., M.. and Jean D. (2014). Impact Of Intellectual Capital Efficiency On The Financial Performance Of Financial Institutions In Yaounde, Cameroon. International Journal of Arts and Commerce, 3(4). pp 166-187.

Bontis, N. (1998). Intellectual Capital: An Exploratory Study that Develops Measures and Models. Management Decision, 36(2), pp. 63-76.

Bontis, N., Keow, W., C., C., and Richardson, S. (2000). Intellectual Capital and the Nature of Business in Malaysia. Journal of Intellectual Capital , 1(1), pp. 85-100.

Bontis, N., Chua, W., and Richardson, S. (2000). Intellectual Capital and the Nature of Business in Malaysia. Journal of Intellectual Capital , 1(1), pp. 85-100.

Brennan, N. and Connell, B. 2000. Intellectual Capital: Current Issues And Policy Implications. Journal of Intellectual Capital, 19(3), pp. 206-240.

Brown, J. S., and Duguid, P. (1998) Organizing Knowledge. California Management Review, 40(3), pp. 90-111.

Cabrita, M., R., and Bonti,s N. (2008). Intellectual capital and business performance in the Portuguese banking industry. International Journal of Technology Management, 43(1-3), pp. 212-237.

Chen, M., C., Cheng, S., J and Hwang, Y. 2005. An Empirical Investigation of The Relationship Between Intellectual Capital And Firms Market Value And Financial Performance. Journal of Intellectual Capital, 6(2). pp.159-176.

Chu, S.K.W., Chan, K.H. and Wu, W.W.Y. (2011). Charting Intellectual Capital performance of The Gateway to China. Journal of Intellectual Capital, 12 (2), pp. 249-276.

Daniel, Zéghal, and Anis Maaloul, (2010). Analysing value added as an indicator of intellectual capital and its consequences on company performance, Journal of Intellectual Capital, 11(1), pp. 39-60

Datta, B. (2014). Performance of Intellectual Capital Management of Indian Public Sector Enterprises. International Journal of Applied Operational Research, 4(1), pp. 27-38. Edvinsson, L., (1997), Developing intellectual capital at Skandia, Long Range Planning, 30(3), pp. 366-373.

Gan, Kin and Saleh, Z. (2008). Intellectual Capital and Corporate Performance of Technology Intensive Companies: Malaysia Evidence. Asian Journal of Business and Accounting, 1(1), pp.113-130.

International Accounting Standards Committee, (1998), IAS 38 Intangible Assets., International Accounting Standards Committee, London.

International Federation of Accountants (IFAC), (1998), The Measurement and Management of intellectual capital, International Federation of Accountants (IFAC), New York.

Moran, P. \& Ghoshal, S. (1996). Value creation by firms. In J. B. Keys \& L. N. Dosier (Eds.), Academy of Management Best Paper Proceedings, 41-45

Muhammad, N. M. N. and Ismail Md. K. A. (2009). Intellectual Capital and Firms's Performance: Study on Malaysian Financial Sectors. International Journal of Economics and Finance, 1(2), pp. 206-212.

Ramirez Y., Tejada A. and Gordillo S. (2013). Recognition of Intellectual Capital Importance In The University Sector. International Journal of Business and Social Research (IJBSR), 3(4). pp. 27-41.

Sumedrea, S. (2013). Intellectual Capital and Firm Performance: A Dynamic Relationship in Crisis Time. Procedia Economics and Finance 6. pp 137-144.

Sullivan, P. H. (1998). Profiting from Intellectual Capital. New York: John Wiley \& Sons, Inc. 
Wernerfelt, B. (1984). A Resource-Based View of the Firm, Strategic Management Journal, 1(5), pp. 171-180.

Zehri C., Abdelbaki A. and Bouabdellah N. 2012. How Intellectual Capital Affects a Firm's Performance? Australian Journal of Business and Management Research. Vol. 2 No. 08.pp 24-31. 